\title{
Passive thermal refugia provided warm water for Florida manatees during the severe winter of 2009-2010
}

\author{
B. M. Stith ${ }^{1, *}$, D. H. Slone ${ }^{2}$, M. de Wit ${ }^{3}$, H. H. Edwards ${ }^{3}$, C. A. Langtimm ${ }^{2}$, \\ E. D. Swain ${ }^{4}$, L. E. Soderqvist ${ }^{5}$, J. P. Reid ${ }^{2}$ \\ ${ }^{1}$ Jacobs Technology, Inc./US Geological Survey, Southeast Ecological Science Center, Gainesville, Florida 32605, USA \\ ${ }^{2}$ US Geological Survey, Southeast Ecological Science Center, Gainesville, Florida 32605, USA \\ ${ }^{3}$ Florida Fish and Wildlife Conservation Commission (FWC), Fish and Wildlife Research Institute (FWRI), St. Petersburg, \\ Florida 33701, USA \\ ${ }^{4}$ US Geological Survey, Florida Water Science Center, Ft. Lauderdale, Florida 33135, USA \\ ${ }^{5}$ US Geological Survey, Florida Water Science Center, Ft. Myers, Florida 33901, USA
}

\begin{abstract}
Haloclines induced by freshwater inflow over tidal water have been identified as an important mechanism for maintaining warm water in passive thermal refugia (PTR) used by Florida manatees Trichechus manatus latirostris during winter in extreme southwestern Florida. Recordsetting cold during winter 2009-2010 resulted in an unprecedented number of manatee deaths, adding to concerns that PTR may provide inadequate thermal protection during severe cold periods. Hydrological data from 2009-2010 indicate that 2 canal systems in the Ten Thousand Islands (TTI) region acted as PTR and maintained warm bottom-water temperatures, even during severe and prolonged cold periods. Aerial survey counts of live and dead manatees in TTI during the winter of 2009-2010 suggest that these PTR were effective at preventing mass mortality from hypothermia, in contrast to the nearby Everglades region, which lacks similar artificial PTR and showed high manatee carcass counts. Hydrological data from winter 2008-2009 confirmed earlier findings that without haloclines these artificial PTR may become ineffective as warm-water sites. Tidal pumping of groundwater appears to provide additional heat to bottom water during low tide cycles, but the associated thermal inversion is not observed unless salinity stratification is present. The finding that halocline-driven PTR can maintain warm water even under extreme winter conditions suggests that they may have significant potential as warm-water sites. However, availability and conflicting uses of freshwater and other management issues may make halocline-driven PTR unreliable or difficult to manage during winter.
\end{abstract}

KEY WORDS: Halocline - Thermal inversion - Tidal pumping · Groundwater · Ten Thousand Islands · Picayune Strand restoration · Everglades restoration · Salinity stratification · Aquatic species

\section{INTRODUCTION}

Large numbers of cold-sensitive wildlife species died in Florida during the record-setting winter of 2009-2010, including endangered species such as manatees, sea turtles, and American crocodiles Croc- odylus acutus, sport fish such as common snook Centropomus undecimalis and tarpon, and exotic species such as freshwater cichlids, pythons, and iguanas (FWRI 2010). Florida recorded its coldest January to March in the $116 \mathrm{yr}$ period of record (NCDC 2010) during this winter. The month of January was espe- 
cially severe, with 175 new lowest daily minimum temperature records and 158 new lowest maximum temperature records set across the state (NCDC 2010). The number of manatee deaths was unprecedented, even in south Florida, with 480 carcasses recorded statewide during 3 mo from January 11 to April 9, 2010, a record number even for any previous 12 mo period (Barlas et al. 2011). This prompted the Working Group on Marine Mammal Unusual Mortality Events to declare an unusual mortality event (UME; Title IV, Marine Mammal Protection Act).

Florida manatees Trichechus manatus latirostris, an endangered sub-species of the West Indian manatee T. manatus manatus, inhabit fresh- and brackishwater rivers, bays, and estuaries in the subtropical regions of Florida and the southeastern United States (northern most limit for this species). Manatees in Florida have a limited ability to thermoregulate in cold water and regularly suffer from cold-related mortality (Irvine 1983, Bossart et al. 2003). Manatees are increasingly seen to retreat to warm-water refugia as water temperatures fall below $20^{\circ} \mathrm{C}$ to avoid cold stress (Deutsch et al. 2003). Most manatees take shelter in power plant effluents or artesian springs during cold periods, but a substantial proportion of the population (typically several hundred manatees) are regularly found at passive thermal refugia (PTR) especially in areas that lack springs or industrial warm water, such as extreme southern Florida (USFWS 2001, Laist \& Reynolds 2005a). These PTR differ from springs or power plants in not having conspicuous, active point sources of warm water inflow. As such, the ability of PTR to adequately support large numbers of manatees during cold winters, even in south Florida, has remained unclear (Laist \& Reynolds 2005a,b).

Recently Stith et al. (2011) studied 2 PTR used by manatees in extreme southwestern Florida and identified the hydrological mechanism that maintained warm water temperatures. The PTR were part of canal systems that received freshwater from upstream and interaction with tidal waters downstream (Fig. 1). The lighter freshwater flows over heavier saltwater, forming a halocline, or sharp, vertical salinity gradient between stratified layers. When sufficient fresh water flow was present, strong vertical salinity gradients provided barriers to convective mixing, which in winter allowed warm bottom water to persist below colder surface water. These beneficial temperature inversions would disappear if no halocline was present due to convective mixing of the water column. The mechanism was identified by analysis of empirical hydrological data collected at

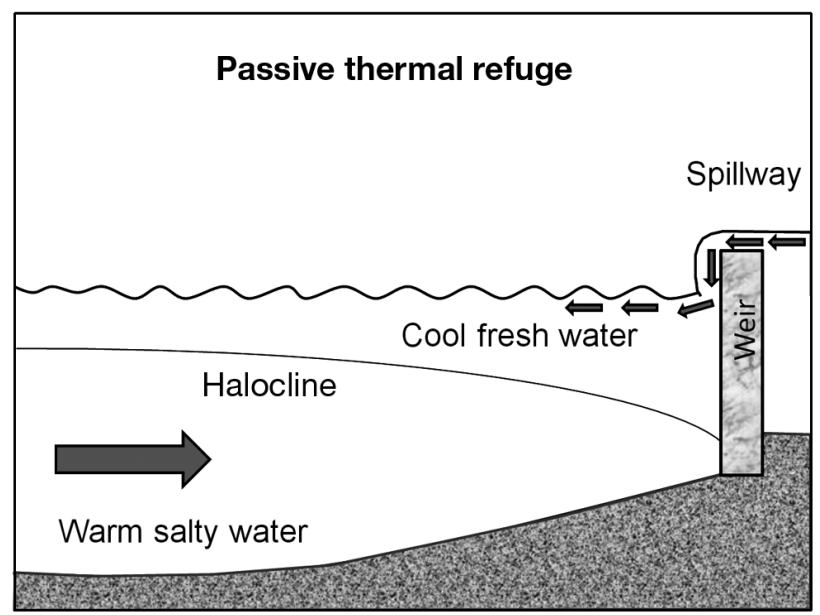

Fig. 1. Halocline conditions at Port of the Islands canal and Faka Union weir showing (large arrow) tidal wedge and (small arrows) freshwater surface layer

the PTR in winter 2006-2007 and 2007-2008 and confirmed by simulations from a 3-dimensional physics-based hydrology model for one of the PTR (Decker et al. 2012).

An understanding of the mechanism that maintains the thermal properties raised the possibility of managing or creating halocline-driven PTR (Stith et al. 2011). However, lack of hydrological data for winters with severe cold periods left open the possibility that factors such as tidal mixing, wind, varying freshwater inputs, or conduction could disrupt the temperature inversion during severe cold. The unprecedented cold of winter 2009-2010 provided data to evaluate the hydrodynamics under extreme conditions. Stith et al. (2011) also noted evidence for a source of bottom heat, indicated by multi-day periods when the bottom layer was warming while the surface layer was cooling, but the source of heat was not determined. We examined additional hydrological data, including canal tidal stage and groundwater level, to look for potential hydraulic head differences and evidence that tidal pumping of groundwater could be a source of heat.

Additionally, the large number of wildlife deaths prompted extensive aerial and boat surveys that supplemented year-round manatee carcass recovery efforts to find and retrieve all carcasses and to determine cause of death. We used these data to assess whether manatee mortality from cold was reduced for manatees in the Ten Thousand Islands (TTI) region, where 2 halocline-driven PTR have been documented, compared to areas to the south in the western coastal Everglades (WCE), which lack similar artificial PTR. This 2 pronged approach allowed us to 
examine whether halocline-driven PTR can function as adequate warm-water refugia for manatees during severe winters in this region.

\section{MATERIALS AND METHODS}

\section{Study area}

Our study area encompassed extreme southwestern Florida, including the southern coastal region of Collier County, centering on the TTI region and extending south to Cape Sable in the Everglades (Fig. 2). We divided the study area into 2 large regions that correspond roughly to the TTI region (west of Turner River to Marco Island) and the western coastal Everglades (Turner River south to Cape Sable) (Fig. 2). Although the 2 regions are very similar ecologically, the underlying geology and historic hydrology has produced pronounced physiographic differences in the 2 regions. The TTI coast is highly dissected with innumerable channels, cuts, and small islands, whereas the Everglades National Park (ENP) is much less dissected with only a few large rivers and large islands (Parkinson 1998). Manatees in the ENP have very few corridors connecting the Gulf of
Mexico and inner bays/rivers, whereas in TTI there are hundreds of pathways. Telemetry data suggest that manatee movements in the 2 areas are very different (USGS unpubl.). Moreover, the availability of artificial warm-water refugia differs between the 2 regions.

The TTI region included the 2 PTR studied by Stith et al. (2011), both associated with dredged canal systems southeast of Naples; one at Port of the Islands (POI), and the second at Big Cypress National Preserve Headquarters (BCNP) (Fig. 2), Ochopee, Florida. POI regularly harbors more than 100 manatees during typical winter aerial surveys (USFWS 2001). Manatees aggregate in the residential canal system at the tidal head of the Faka Union (FU) Canal, which is directly downstream from the Picayune Strand Restoration Project. The restoration project will remove or plug most of the $77 \mathrm{~km}$ canal system that was completed in 1971 to drain a failed real estate development that is now under public ownership (US Army Corps of Engineers and South Florida Water Management District 2004). The PTR at BCNP consists of dredged canals that receive freshwater from the Big Cypress Basin, with a shallow, circuitous, and lengthy tidal connection to Chokoloskee Bay via Halfway Creek.

The western coastal Everglades region has a nearly continuous coastline with 5 large rivers connecting the Gulf of Mexico to an extensive set of inner bays, the largest being Whitewater Bay at the southern end. Several small winter aggregation sites for manatees, the most noteworthy of which being Mud Bay, have been identified based on winter aerial surveys (Stith et al. 2006) and a USGS telemetry study (USGS unpubl. data). Conversely, the WCE region lacks canal systems, like POI or BCNP, that are designed to drain wetlands and are accessible to manatees. The few canals that exist, such as Buttonwood Canal and boat basin complex at Flamingo, were designed as transportation shortcuts for boats, rather than as parts of a drainage project that receives freshwater discharge.

Water depths in the canals at POI average around 2.5 to $3.0 \mathrm{~m}$ with a few deeper holes reaching 3.5 to $4.5 \mathrm{~m}$. The canals at BCNP are considerably deeper, averaging around 5.0 to $6.0 \mathrm{~m}$ with some deeper sections reaching 7.0 to $8.5 \mathrm{~m}$. Wa-
Fig. 2. Study area showing the Ten Thousand Islands (TTI) and western coastal Everglades regions, separated by a bold dashed line. The 2 artificial passive thermal refugia (PTR) in TTI at Port of the Islands (POI) and Big Cypress National Park are shown, along with a natural PTR, Mud Bay, in the Everglades. SGT5W3 is a ground water monitoring well approximately $3 \mathrm{~km}$ from POI 
ter depths at Mud Bay average around 1.2 to $1.6 \mathrm{~m}$, with discrete deeper holes reaching 2.5 to $3.0 \mathrm{~m}$.

\section{Manatee data}

Special aerial and boat surveys were conducted to search systematically for manatee carcasses, as well as American crocodile and other cold-sensitive species, throughout WCE and TTI during mid to late January 2010. Locations of carcasses were recorded on maps and via GPS. Reports of carcasses were also obtained from other sources such as boaters and fishermen.

Carcasses were verified and recovered whenever possible. Necropsies were conducted either on site or at the Fish and Wildlife Research Institute (FWRI) Marine Mammal Pathology Laboratory in St. Petersburg, Florida to identify cause of death.

We restricted our analysis of carcass data to a $2 \mathrm{wk}$ period (January 13 to 28, 2010) because the most intensive sampling effort occurred during this period and was relatively uniform across the study area. This period also overlapped the first and most severe cold weather of the 2010 winter, when immediate death from acute cold shock rather than prolonged decline from chronic cold stress was most likely (Bossart et al. 2003, Barlas et al. 2011). The short time frame between extreme cold and carcass recovery made it more probable that an individual would have died in the area where it experienced severe cold.

On January 14, 2010 the Florida Wildlife Commission (FWC) flew its annual winter manatee synoptic aerial survey during the first extended cold spell, providing an initial snapshot of the distribution of live animals as the mortality event unfolded. These statewide (synoptic) aerial surveys cover manatee habitat in the major river systems, inland bays, shallow Gulf shoals, and all known primary and secondary manatee winter aggregation sites in the study area. Synoptic surveys (Ackerman 1995) follow a standardized protocol and flightlines; however both have been modified slightly over the past $20 \mathrm{yr}$ as more information about survey timing and manatee distribution has been ascertained. Because of factors such as survey design, availability and heterogeneous detection of manatees, counts from these surveys are usually considered underestimates (minimum counts) and are not true estimates of abundance (Edwards et al. 2007, Fonnesbeck et al. 2009). The synoptic survey data allowed us to compare the number of reported carcasses to the number of live manatees seen in TTI and WCE.

\section{Hydrological data and analysis at the PTR}

As a continuation of prior research (Stith et al. 2011), we monitored the temperature and salinity at POI and BCNP for 2 additional winters (2008-2009 and 2009-2010) to characterize the vertical temperature and salinity regime. At each site we deployed 2 YSI 600 XLM water quality sondes within $15 \mathrm{~cm}$ of the surface using a floating mount, and the other within $15 \mathrm{~cm}$ of the bottom. Date and time, temperature, conductance, and salinity (calculated using temperature and conductance) were logged every $15 \mathrm{~min}$.

In 2009-2010 we added a vertical string of thermistors to the monitoring station at POI to record temperatures at $30 \mathrm{~cm}$ vertical increments, with the deepest thermistor buried $30 \mathrm{~cm}$ into the mud layer, and the shallowest $168 \mathrm{~cm}$ above the mud. The mud temperature was of special interest because bottom-resting manatees were often seen partially coated in mud as they rose to the surface to breathe, suggesting that mud temperatures might be warmer than bottom water ones, as noted by Stith et al. (2011).

Temperature, salinity, and stage data from a groundwater monitoring well near POI (SGT5W3; location on Fig. 2; approx. $3 \mathrm{~km}$ from POI) were obtained from the South Florida Water Management District (SFWMD) DBHYDRO data website (www. sfwmd.gov) for 2 winters (2008-2009 and 20092010). We investigated data from another nearby well (SGT5W2) but did not use these data because the groundwater was much less saline than both SGT5W3 and the POI bottom water, and SGT5W2 stage data showed large, non-tidal fluctuations that were absent at SGT5W3. We also obtained stage data (3 to $4 \mathrm{~min}$ intervals and daily averages) from just downstream of the FU-1 weir to investigate the role of tidal fluctuations in the canal. The uneventime-interval tidal data were interpolated to match the 15 min interval groundwater stage.

We plotted surface and near-bottom temperature and salinity data in vertical panels for the 2 winters for both sites. We plotted groundwater temperature data for SGT5W3 with the POI mud and water temperature data to see if groundwater was a possible source of bottom heat. We also plotted groundwater levels and tidal stage in the canal as an indicator of differences in hydraulic head and possible tidal pumping (Ganju 2011). Discharge calculations for the FU-1 weir at POI were obtained from DBHYDRO (SFWMD website). Discharge at BCNP was estimated by USGS at bimonthly intervals using 
velocity profile measurements and a cross-section estimate. Discharge data were plotted for POI and BCNP in vertical panels with temperature and salinity data.

Vertical profiles of salinity and temperature were measured during a peak cold period on January 8, 2010 along a north-south gradient from just upstream of the FU-1 weir to the southern end of the canal at the Faka Union Bay (6 sampling locations, see Appendix, Fig. A1). Three sites were within side canals in deeper holes used by manatees. These data allowed us to characterize the depth of the freshwater layer and the spatial extent of the salinity stratification in the canal system.

Following the approach of Stith et al. (2011), we calculated the density of water at the surface and bottom for POI (Fofonoff \& Millard 1983). We used data from both winters to portray a wide range of values under stratified and unstratified conditions. For each pair of bottom-surface measurements, we plotted the vertical difference in temperature and salinity, for 3 surface temperature thresholds representing increasingly stressful conditions for manatees $\left(<20, \leq 18, \leq 16^{\circ} \mathrm{C}\right)$. We also calculated the density differences between the bottom and surface and overlaid a contoured surface of these density differences on a plot of the corresponding vertical salinity and temperature differences. The plot emphasizes extreme cold temperatures $\left(\leq 16^{\circ} \mathrm{C}\right)$ not found in previous years (Stith et al. 2011), with density contours to show whether warmer, more saline bottom water remained denser than extremely cold surface water, and whether larger density differences were associated with stronger salinity stratification.

Correlation analyses were conducted for data at POI as in Stith et al. (2011) to examine relationships among several factors: (1) temperature difference (bottom minus surface), (2) salinity difference (bottom minus surface), and (3) freshwater discharge. We examined the relationship between freshwater discharge and temperature inversion to test the hypothesis that increasing flow rates and decreasing surface water temperatures would result in smaller temperature inversions. For this analysis we binned the surface temperatures into 4 categories $\left(>20^{\circ} \mathrm{C}, 17.99\right.$ to $20^{\circ} \mathrm{C}, 16$ to $18^{\circ} \mathrm{C}$, and $<16^{\circ} \mathrm{C}$ ). We also examined the relationship between an indicator of head difference, measured as groundwater level minus tide stage, versus vertical temperature difference (bottom minus surface) to test the hypothesis that larger head differences were associated with larger temperature inversions.

\section{RESULTS}

\section{PTR temperature inversions and stratification}

Winter 2008-2009

Bottom temperatures at POI remained above $20^{\circ} \mathrm{C}$ and temperature inversions were strong for the first half of the winter, then became cold and fluctuated in near-synchrony with the surface as the halocline disappeared in the second half of the winter (Fig. 3). During this period with no salinity stratification, the bottom temperature still cooled more slowly than the surface, showing a thermal lag of 1 or $2 \mathrm{~d}$. Freshwater discharge was highest at the start of winter, and declined steadily to 0 by mid-February. This association between loss of discharge and loss of temperature-inverted haloclines is similar to 2006-2007, as reported by Stith et al. (2011; Fig. 3). Brief periods can be seen during both winters when the bottom was warming while the surface was cooling (example in Fig. A2), but only when a halocline was present. As with all other years reported here and in Stith et al. (2011), BCNP bottom temperatures were substantially warmer and more stable than POI. Discharge was much lower in 2008-2009 at BCNP than in 2009-2010, with bi-monthly readings falling close to 0 by early December (Fig. 4). Accordingly, 20082009 was the only winter when the halocline disappeared at BCNP (end of February 2009), and during this period the bottom temperatures fluctuated much more strongly than any other year (Fig. 4). Surface waters were rapidly warming at that time, so the bottom water at BCNP did not dip below $20^{\circ} \mathrm{C}$.

\section{Winter 2009-2010}

Bottom temperatures remained above $20^{\circ} \mathrm{C}$ and strong temperature inversions persisted at POI throughout the severe winter of 2009-2010 (Fig. 5) with the exception of some brief bottom temperature dips to 18 to $19^{\circ} \mathrm{C}$ for a $1 \mathrm{wk}$ period in mid-January. The temperature of the mud layer at POI remained above $22^{\circ} \mathrm{C}$ for the entire winter. During several cooling and warming cycles, a de-coupling of the bottom and surface temperatures was evident at POI, with the bottom layer warming while the surface was cooling (Fig. 6). These bottom-warming, surfacecooling trends lasted multiple days, making it unlikely that the semi-diurnal tidal movement of water bodies with different temperatures could explain the observed patterns. The bottom-warming, surface- 


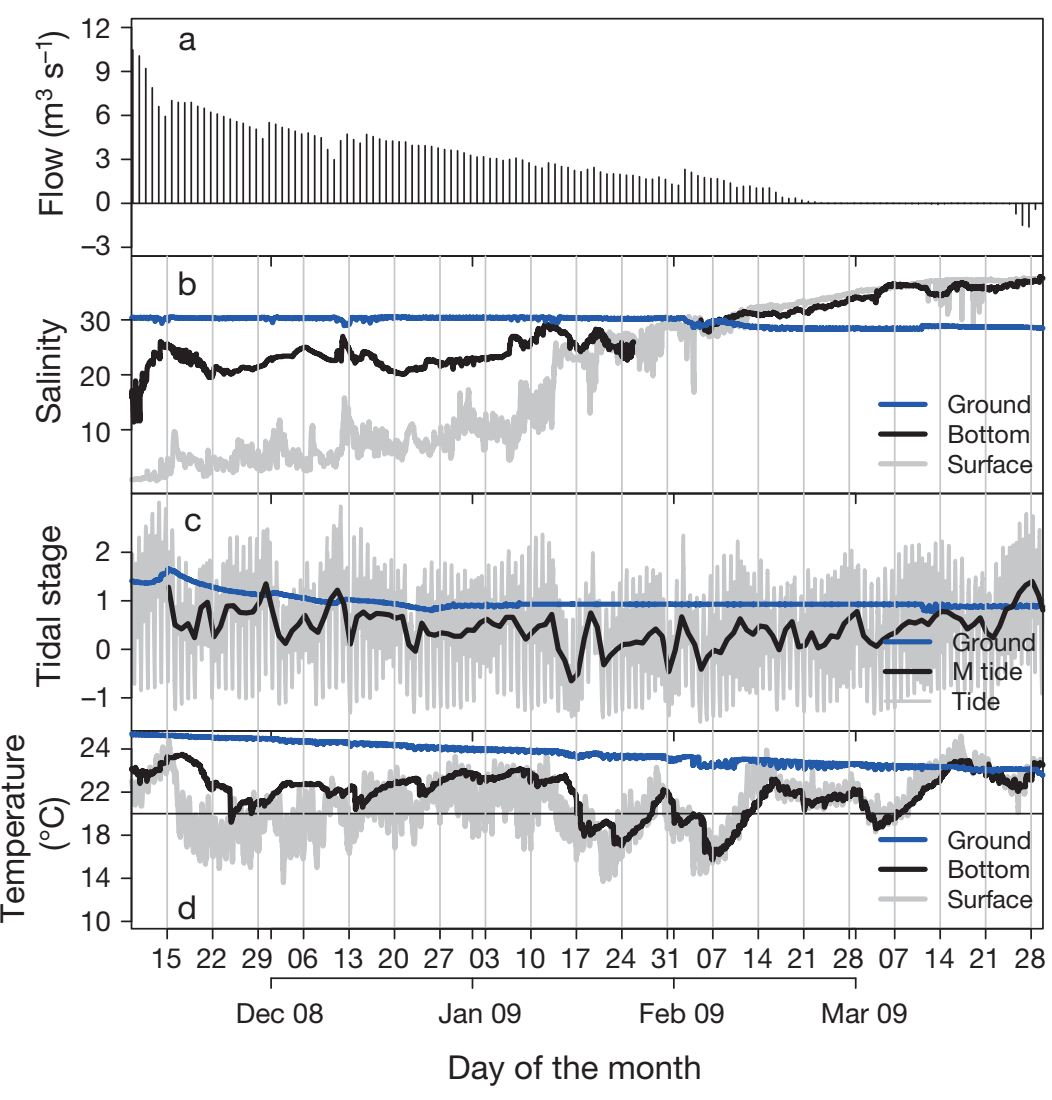

Fig. 3. Port of the Islands (POI) (a) POI daily mean discharge, (b) POI surface, bottom, and SGT5W3 groundwater salinity, (c) SGT5W3 groundwater level and POI tide stage (15 min interval, Tide; and daily mean, M tide), and (d) SGT5W3 groundwater, POI surface and bottom temperatures at $15 \mathrm{~min}$ intervals for winter 2008-2009

cooling trends indicate a source of bottom heat separate from surficial interactions.

Freshwater discharge was continuous during winter 2009-2010, fluctuating around $6 \mathrm{~m}^{3} \mathrm{~s}^{-1}$ for most of the winter (Fig. 5). The continuous discharge and persistent halocline can be attributed to above average winter precipitation (NCDC 2010). BCNP bottom temperatures were substantially warmer and more stable than those at POI, remaining above $24^{\circ} \mathrm{C}$ nearly the entire winter (Fig. 4). Positive freshwater discharge at BCNP was not as large as at POI, remaining below $2 \mathrm{~m}^{3} \mathrm{~s}^{-1}$ during all but 1 bi-monthly reading (Fig. 4).

\section{Density relationships}

Density relationships in 2008-2009 and 2009-2010 were similar to the previous 2 winters reported in Stith et al. (2011), showing greater densities in the bottom versus surface even when the surface was much colder than the bottom, unless there was no salinity stratification. A major difference was the large number of hourly readings that fell below $16^{\circ} \mathrm{C}$ at the surface in 2009-2010 (Fig. 7), compared to virtually none in all previous years. These coldest points were associated with the largest temperature inversions observed during all years, but still fell within the most stable region where density differences were largest. The near vertical orientation of the density contours indicates that salinity had a stronger influence on density than temperature for the observed conditions, allowing the maintenance of these large temperature inversions.

\section{Surface water discharge, salinity stratification, and temperature inversion}

The salinity difference between the bottom and surface at POI for the 2008-2009 and 2009-2010 winters was strongly correlated with upstream freshwater discharge over the POI weir (Fig. 8; Pearson's coefficient $=$ 0.699, $\mathrm{df}=230, \mathrm{p}<0.0001)$ and was very similar to previous years (Fig. 10 of Stith et al. 2011). The relationship between discharge and temperature inversion for different ranges of surface temperatures (Fig. 9) indicated that temperature inversions increased as flow increased and as surface temperatures decreased. However, a limit must exist where a sufficiently large, longduration flow rate at a sufficiently low enough temperature would cause the bottom to cool to detrimentally low temperatures (Decker et al. 2012). This limit was not reached in the observed data and appears to be unlikely, given that the largest flow rates are associated with the warmer wet season.

\section{Salinity profile}

The vertical profile data at different locations within POI on January 8, 2010 showed a pronounced halocline across most of the upper canal system. A fresh or brackish water layer at the surface ranged from 0.33 to $1 \mathrm{~m}$ in depth, with the 


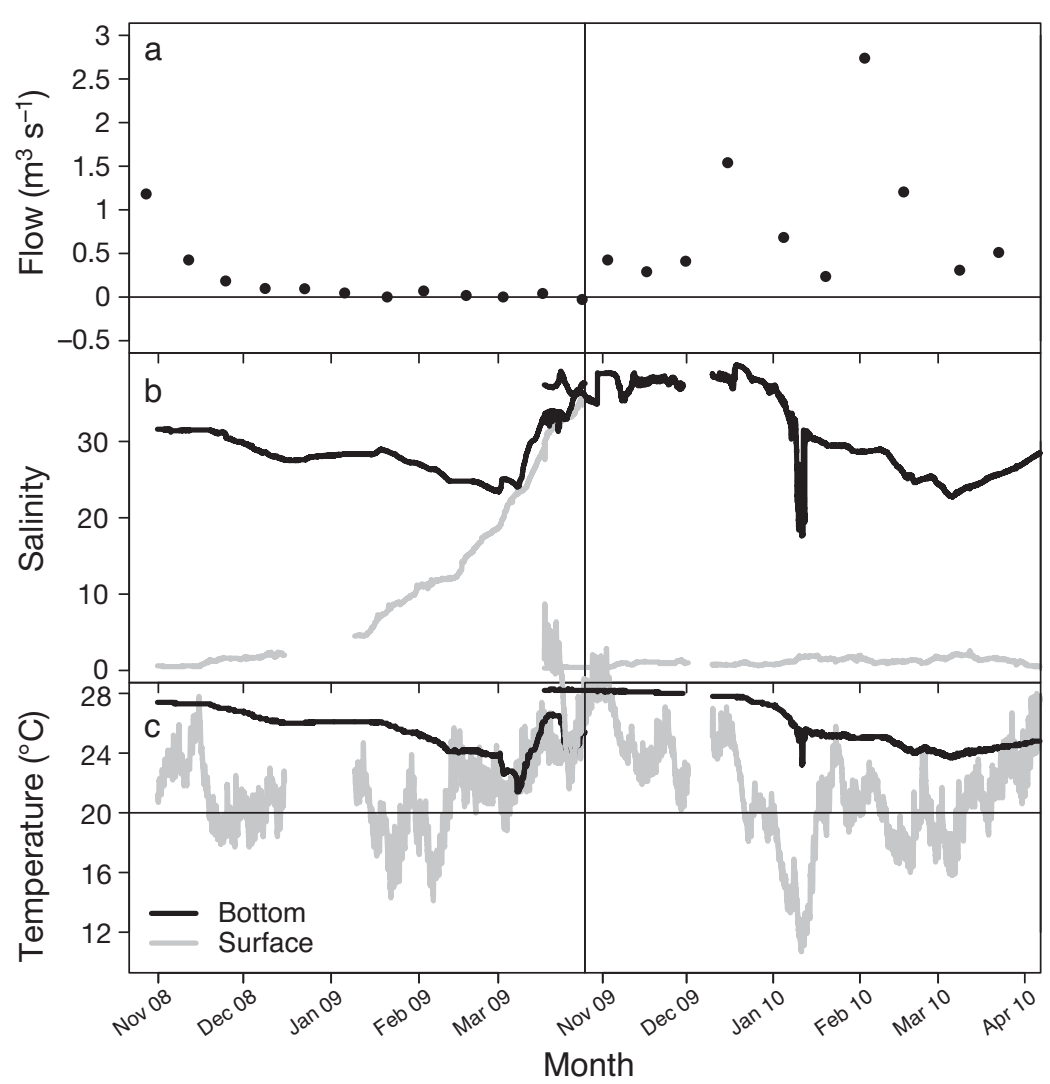

Fig. 4. Big Cypress National Park (a) daily mean discharge, (b) surface and bottom salinities, and (c) surface and bottom temperatures at 15 min intervals for winter 2008-2009 and winter 2009-2010

greater depth of the surface layer occurring nearer to the source of freshwater (Appendix, Fig. A3). The 2 sites in the main canal showed higher salinities in the upper layer (15 to 18$)$ than in the side canals. The southern entrance to the canal $(5 \mathrm{~km}$ downstream of POI) had no stratification and showed uniformly high salinities that were equivalent to Faka Union Bay.

\section{Tidal pumping and groundwater discharge}

During several major cold periods, bottom temperatures showed warming trends even while surface temperatures were rapidly declining and colder than the bottom (Figs. 6 \& A2). These bottom-warming, surface-cooling trends occurred during downward trending or extreme low tides that are usually associated with the passage of strong cold fronts, suggesting that tidal pumping was advecting warm groundwater into the bottom canal water. A significant correlation was found between the hydraulic gradient (groundwater stage minus tidal stage) and the temperature difference between the bottom and surface layer for winter 2009-2010 (Fig. 10, surface $<16^{\circ} \mathrm{C}_{\text {; }}$ Pearson's coefficient $=0.46, \mathrm{df}=1523$, $\mathrm{p}<0.0001$ ).

Stable isotope analysis conducted for another study indicated that the bottom water at POI has tidal water from the Gulf as its primary source (USGS unpubl. data), suggesting that the groundwater is recirculated seawater that has intruded into the surficial aquifer around the canal.

\section{Live and dead manatees}

Aerial survey counts of live manatees in the TTI region were more than twice that of the WCE region (Table 1; 166 and 75 ind., respectively). Seventy-five percent of the total count for TTI occurred at the 2 PTR. The largest manatee aggregation in the WCE region was at Mud Bay (45 ind.), accounting for $60.0 \%$ of the total count in WCE. Because of heterogeneous detection rates and other issues, these survey results represent minimum counts.

Counts of dead manatees, however, were many fewer in TTI compared to WCE (Table 1; 11 and 76 ind., respectively). Between January 13 and 28, 2010, a total of 5 carcasses were found at POI and the Faka Union Canal connecting it to the Gulf, with 6 additional carcasses recovered throughout the rest of the TTI region. Cause of death was determined to be cold related for all but 2 of the carcasses from POI and TTI. Because of the remoteness and inaccessibility of many of the carcasses in WCE, 65 of the 75 were verified but because a full necropsy was not performed, cause of death could not be determined. Cold-related causes were identified for the remaining 10 carcasses and strongly implicated in the 65 others due to the exceptionally high number of carcasses found associated with the brief, unprecedented cold period.

Carcass counts for the remainder of the winter (January 29 to March 19) showed a similar pattern, with an additional 26 carcasses with undetermined cause of death reported in WCE, and 8 cold-related carcasses ( 7 cold-related, 1 with undetermined cause of death) found in the TTI region (4 at POI or the Faka Union Canal). 


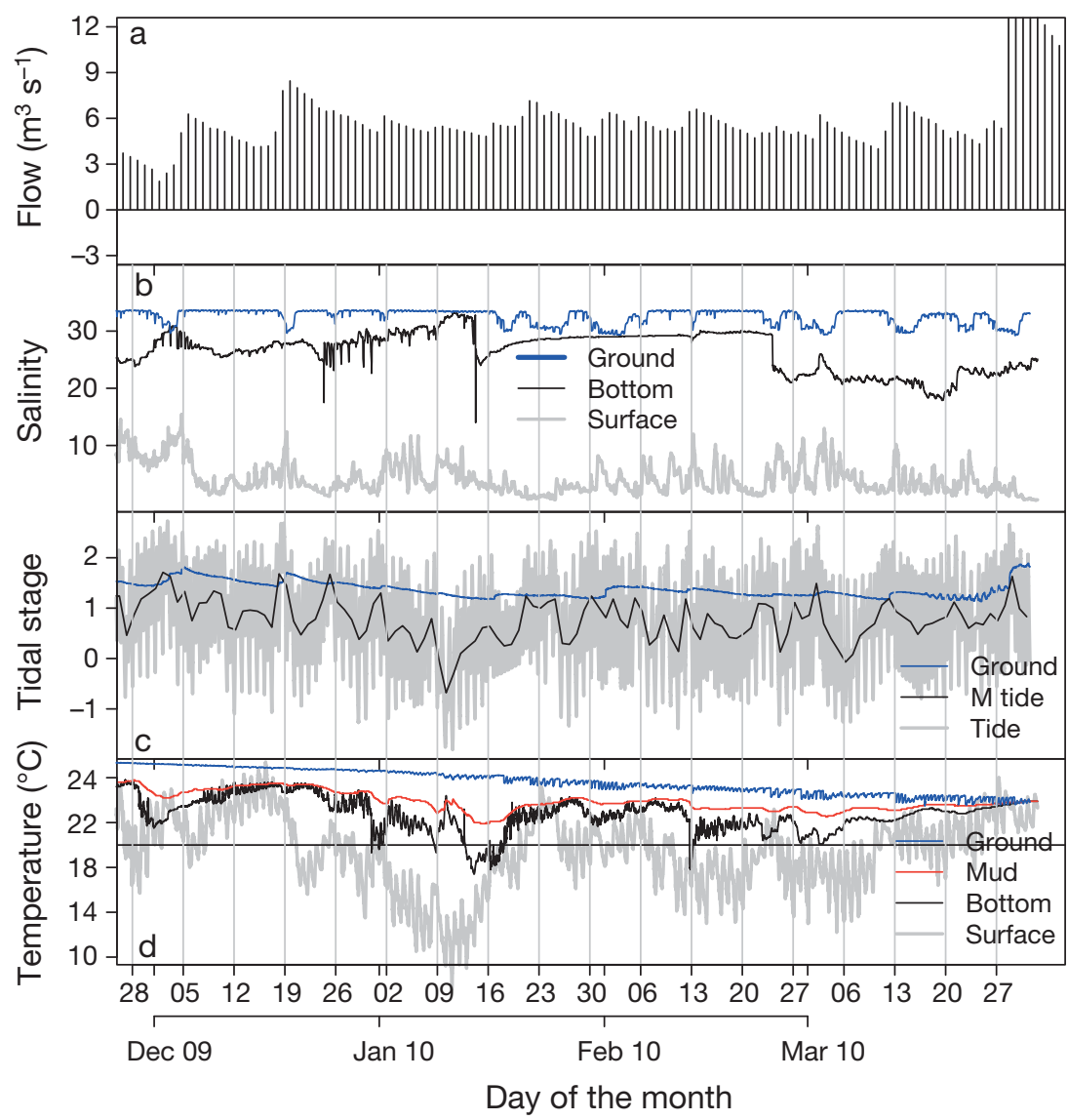

Fig. 5. Port of the Islands (POI) (a) POI daily mean discharge (b) POI surface, bottom and SGT5W3 groundwater salinity, (c) POI tide stage (15 min interval, tide; and daily mean, M tide) and SGT5W3 groundwater level, and (d) temperatures for POI shallow mud, surface, bottom, and SGT5W3 groundwater at 15 min intervals for winter 2009-2010

\section{DISCUSSION}

Despite the record-setting cold temperatures during the severe winter of 2009-2010, the PTR at POI and BCNP maintained bottom water near or above $20^{\circ} \mathrm{C}$, providing temperatures sufficiently warm for most manatees to avoid severe cold stress or hypothermia (Bossart et al. 2003, Laist \& Reynolds 2005a). The large counts of live manatees at these 2 PTR and the relatively small carcass counts in the associated TTI region contrasted sharply with WCE, where a large number of manatees were found dead, most likely because they did not have access to PTR that functioned as well as POI or BCNP as warm-water refugia. Although detection rates, survey effort, and other factors undoubtedly differed between regions, such biases seem unlikely to account for the large differences in the number of dead and live manatees detected in the 2 regions. The small carcass count and large live count in the TTI region can be explained parsimoniously by the availability of warm water we measured at POI and BCNP during this record-setting cold, suggesting that these PTR played an important role as warm-water sites for manatees in this region.

The findings that PTR provided warm water even during severe cold are significant because uncertainty exists about the ability of PTR to function adequately as warm-water refugia (Laist \& Reynolds 2005b). PTR are generally thought to provide marginal or unreliable warm water compared to the 2 major sources of warm water used by most manatees: springs and industrial thermal effluent (primarily power plants) (Laist \& Reynolds 2005a,b). Possible loss of major warmwater sites, due to power plant shutdowns or reductions of spring flow, has been identified as a significant threat to the long-term viability of the manatee population, second only to watercraft mortality (Runge et al. 2007). PTR could become more attractive or important to manatees with the loss of warm-water sites. A complicating factor is that various larger scale changes, such as water-management policies or climate change, could alter the availability of freshwater at PTR and perhaps the temperature regimes. Thus, understanding the mechanisms responsible for providing warm water at PTR has been identified as important to the management and recovery of manatees (USFWS 2001, FFWCC 2007).

Multiple mechanisms appear to operate at POI and BCNP to create and maintain warm water, and similar mechanisms may operate at other PTR in Florida. We suggest 3 primary mechanisms can be used to characterize PTR: (1) thermal inertia, (2) salinity stratification, and (3) groundwater discharge. All 3 of these mechanisms may operate at a given site. Salinity stratification and groundwater discharge may be absent or operate intermittently or continuously at a given PTR, resulting in different warm-water regimes. Thus, identifying the dominant mechanisms may be important to understanding the conditions under which a site might be unreliable or manageable as a winter refuge.

Thermal inertia is a mechanism that is present at many PTR simply because they have greater depths 


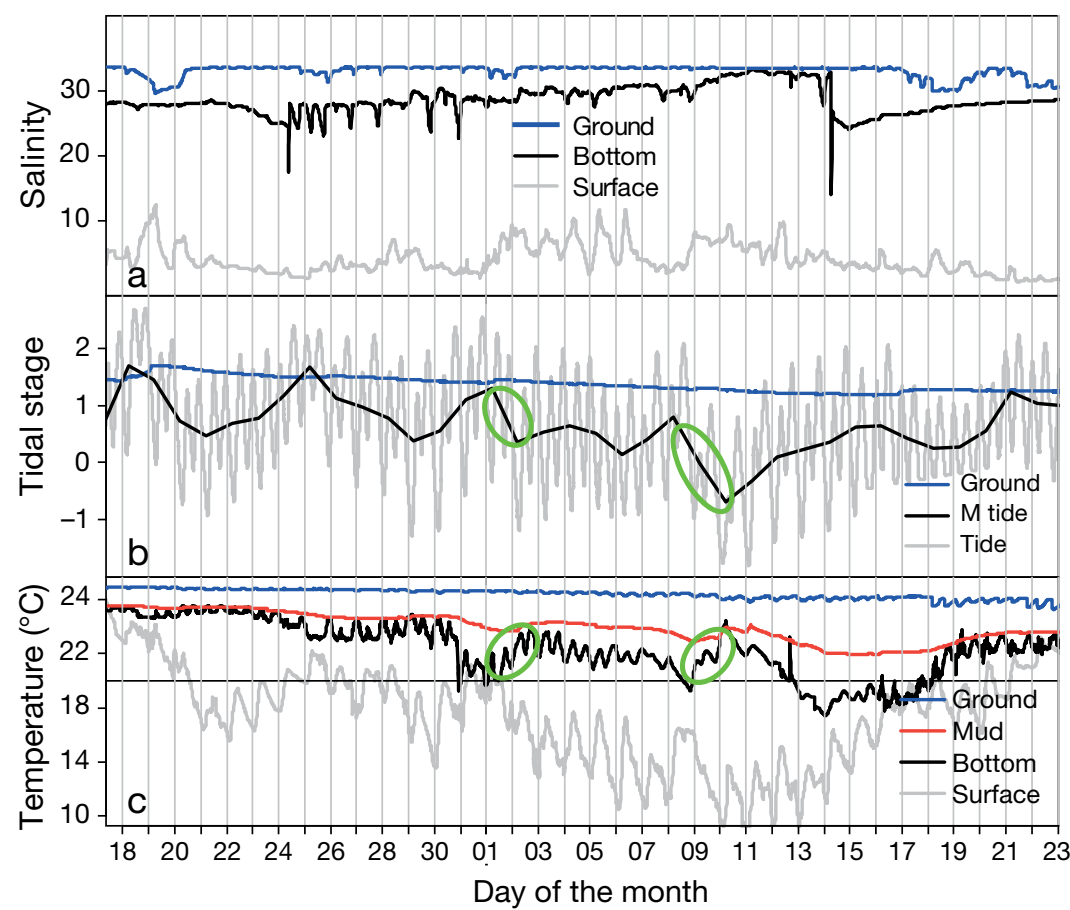

Fig. 6. Port of the Islands (POI), Dec-Jan 2010. (a) POI surface, bottom, and SGT5W3 groundwater salinity, (b) POI tide stage (15 min interval, tide; and daily mean, M tide) and SGT5W3 groundwater level, and (c) temperatures for POI shallow mud, surface, bottom, and SGT5W3 groundwater. (b) Green ellipses show low tide cycles associated with strong cold events. (c) Green ellipses show corresponding periods with bottom-water warming, surfacewater cooling

compared to other water bodies used by manatees. Typical artificial PTR consist of dredged canals or basins with increased depths that increase thermal mass, have small surface dimensions relative to volume that reduces heat loss to the atmosphere, and are narrow with limited fetch that reduces wind-induced convection (Stith et al. 2011). A 3-dimensional hydrology model of POI showed that increasing canal depth by $1 \mathrm{~m}$ substantially reduced the time duration of bottom temperatures falling below $20^{\circ} \mathrm{C}$ (Decker et al. 2012). This simulated thermal inertia effect occurred in the absence of salinity stratification. A thermal iner-

Fig. 7. Vertical differences (bottom minus surface) at Port of the Islands for salinity versus temperature and correlations when surface temperatures were below $16^{\circ} \mathrm{C}$ (large black circles and thick black line), below $18^{\circ} \mathrm{C}$ (small black circles and thin black line), or below $20^{\circ} \mathrm{C}$ (small open circles and dashed line) for winter 2008-2009 and 2009-2010. Points with positive temperature differences show temperature inversions (bottom warmer than surface). Contours indicate vertical density differences ( $\mathrm{kg} \mathrm{m}^{-3}$; bottom to surface), with neutral density occurring at the zero contour and increasingly stable configurations (bottom denser than surface) occurring at points further to the right tia effect can be seen at POI in the second half of winter 2008-2009 (Fig. 3), when salinity stratification was absent. Warmer minimum bottom temperatures and a delay in cooling occurred compared to the surface temperatures. The observed thermal lags were brief, lasting 1 or $2 \mathrm{~d}$, and bottom temperatures still fell below $20^{\circ} \mathrm{C}$ during strong cold fronts. A similar pattern was seen at the Matlacha, Florida, PTR, where Barton (2006) concluded that the warmer temperature of the canals was due to heat retention associated with greater depths and reduced tidal flushing. Thermal inertia may provide warm bottom-water at PTR during cold periods that are mild or short in duration. However, during severe or prolonged cold periods, the bottom temperatures may become excessively cold if thermal inertia is the only mechanism reducing heat loss. Under such conditions, these PTR are likely to be unreliable as warm water refugia (Barton 2006, Stith et al. 2011) and may function as temporary stopovers for migrating or foraging manatees under mild winter conditions (Deutsch et al. 2003).

Another heat-related mechanism that may be significant in some PTR is groundwater discharge. Springs have groundwater discharge that is characterized as laminar flow through vents or seeps (Scott et al. 2004), whereas at PTR groundwater discharge,

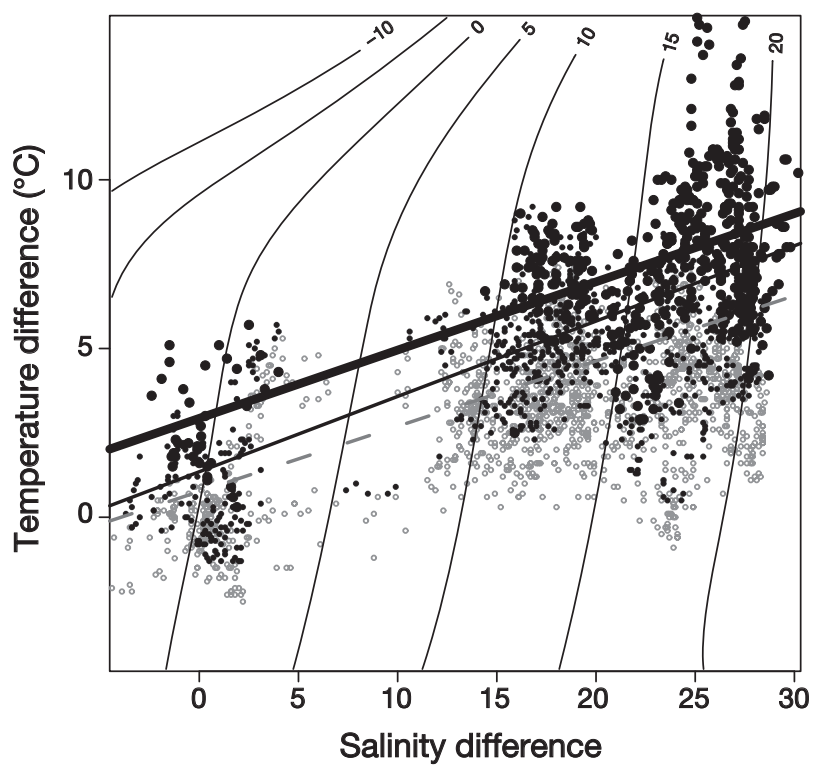




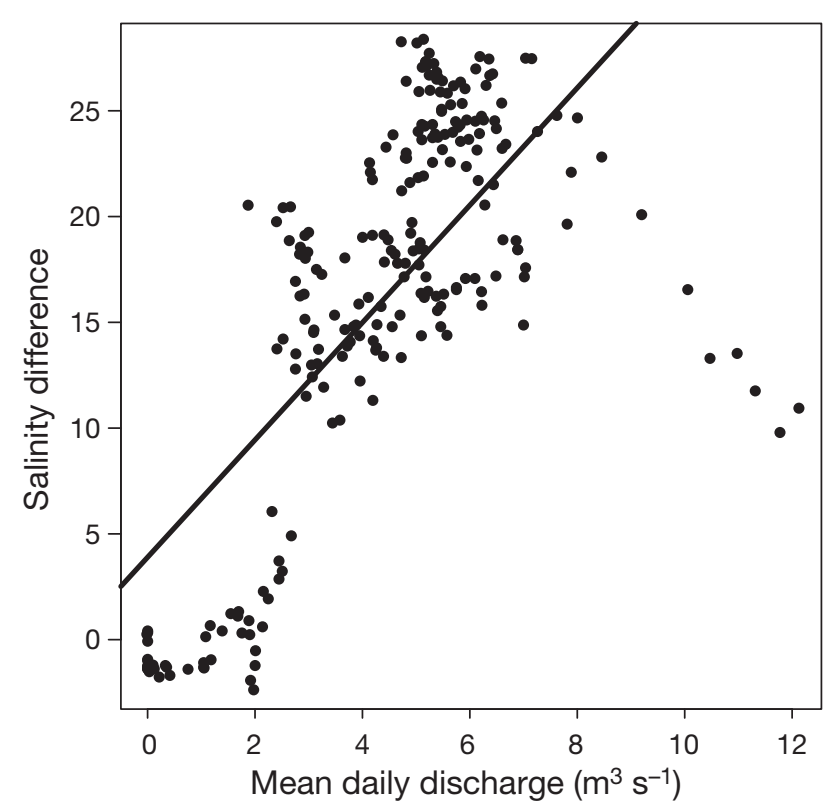

Fig. 8. Correlation between salinity difference (bottom to surface) versus freshwater discharge at Port of the Islands for winter 2008-2009 and 2009-2010

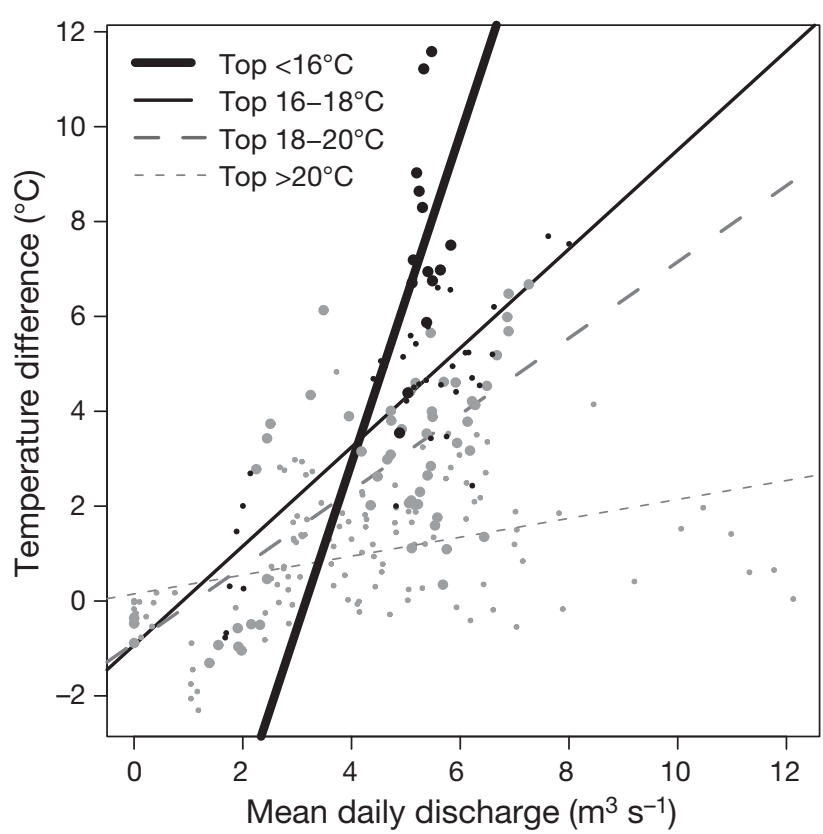

Fig. 9. Correlation between freshwater inflow and temperature difference (bottom minus surface) when surface temperatures were below $16^{\circ} \mathrm{C}$ (large black circles and thick black line), $16-18^{\circ} \mathrm{C}$ (small black circles and thin black line), $18-20^{\circ} \mathrm{C}$ (large gray circles and thick dashed line) and above $20^{\circ} \mathrm{C}$ (small gray circles and thin dashed line), at Port of the Islands for winter 2008-2009 and 2009-2010

if present, is more diffuse and generally lacking observable point sources. Groundwater entering PTR typically comes from unconfined surficial aquifers rather than artesian aquifers (Laist \& Reynolds 2005a).

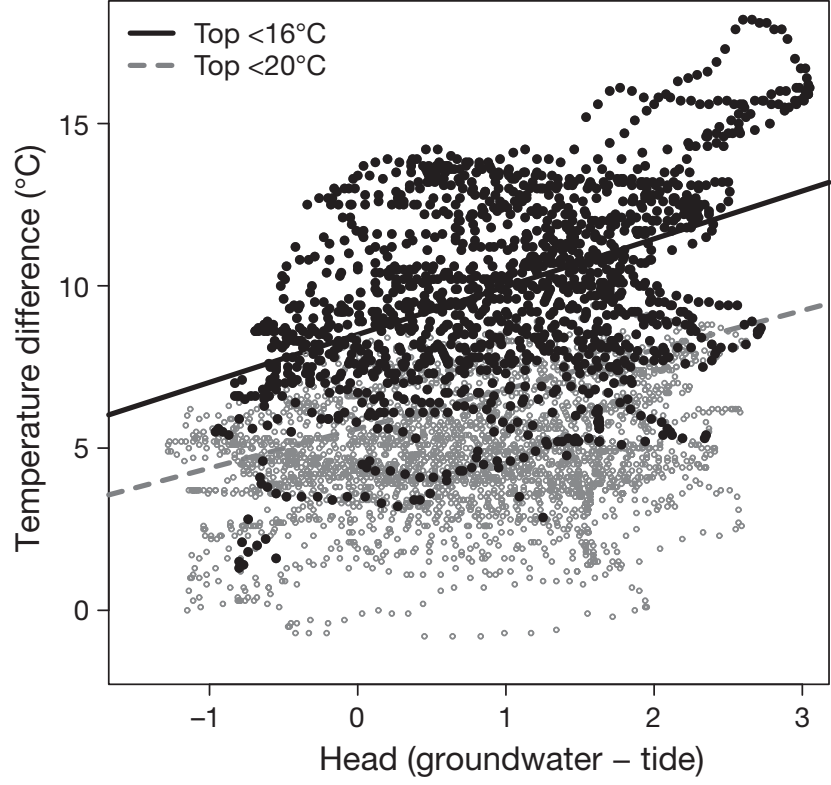

Fig. 10. Port of the Islands (POI) temperature differences (bottom minus surface) versus index of hydrologic head (groundwater stage minus tidal stage) and correlations when surface temperatures were below $16^{\circ} \mathrm{C}$ (dark heavy points and black correlation line) or $16-20^{\circ} \mathrm{C}$ (small grey circles and gray dashed correlation line) for winter 2009-2010. Points with positive temperature differences indicate temperature inversions (bottom warmer than surface). Points with positive head indicate groundwater levels higher than tidal stage

Table 1. Trichechus manatus latirostris. Number of live and dead manatees counted from 13 to 29 Jan 2010 at the major aggregation site of the Port of the Islands and within the Ten Thousand Islands and western coastal Everglades (WCE) regions. Cause of death could not be determined for most carcasses in the SW Everglades

\begin{tabular}{|lcc|}
\hline Location & $\begin{array}{c}\text { No. of } \\
\text { live indi- } \\
\text { viduals }\end{array}$ & $\begin{array}{c}\text { No. of carcasses } \\
\text { (no. with unde- } \\
\text { termined cause } \\
\text { of death) }\end{array}$ \\
\hline $\begin{array}{l}\text { Port of the Islands } \\
\begin{array}{l}\text { Ten Thousand Islands Region } \\
\text { (including Port of the Islands) }\end{array}\end{array}$ & 135 & $5(1)$ \\
WCE & 75 & $11(2)$ \\
$75(65)$
\end{tabular}

Head pressure in surficial aquifers is relatively small due to the shallow elevational gradients found in Florida (Reich 2010). Nevertheless, groundwater discharge can be a significant heat source in canals, rivers, and other water bodies, and heat measurements are commonly used as a groundwater tracer (Anderson 2005, Constantz et al. 2008). If a PTR has a strong halocline that suppresses vertical mixing, even a relatively small volume of warm groundwater 
seepage could be held in a thin layer at the bottom that retains a significantly higher temperature. Shallow groundwater in south Florida is typically substantially warmer than $20^{\circ} \mathrm{C}$ even during winter (Fig. 3), and in some areas discharge rates are sufficient to maintain warm water temperatures even during severe cold. For example, the freshwater L31 canal on the east side of the Everglades acted as a groundwater-driven PTR for nonnative freshwater fish during the severe cold of January 2010 (Harvey et al. 2011) and remained above $17^{\circ} \mathrm{C}$ during the coldest period. Coastal canals in nearby Coral Gables provide a well-known manatee PTR (Laist \& Reynolds 2005a,b), as do some other canals in the extensive multi-county canal system, which receive significant warm groundwater discharge from the shallow, porous Biscayne aquifer (Renken et al. 2005).

At POI, a distinctive heat signature of groundwater discharge can be seen during the extreme cold periods of 2009-2010, when bottom temperatures showed multi-day warming trends even while the colder surface water rapidly declined in temperature (Fig. 6). These heat signatures are associated with periods of average downward trending or extreme low tides, when canal water levels were low compared to groundwater levels. The correlation analysis also showed that larger head differences created by low tide cycles were associated with larger temperature inversions. These are good indicators that tidal pumping (Ganju 2011) was advecting warm groundwater into the bottom water during low tidal periods of winter 2009-2010, allowing bottom water to warm independently of the colder surface water. Similar bottom-warming, surface-cooling trends can be seen during the first half of winter 2008-2009, but are absent during the second half, when salinity stratification was no longer present (Fig. 3). This suggests that salinity stratification was needed to retain groundwater heat that was advected into the bottom layer.

Salinity stratification appears to be a key mechanism maintaining warm water at POI, and freshwater inflow is needed to create salinity stratification (Fig. 8; Stith et al. 2011). Loss of salinity stratification was associated with reduction and loss of upstream freshwater discharge in winter 2008-2009. Numerical experiments indicated that the observed thermal inversions with warm bottom water temperatures would not exist for any significant period of time if salinity stratification was not represented (Decker et al. 2012). Even though surface water temperatures in 2009-2010 were colder than previously recorded years (Stith et al. 2011), the temperature inversions not only persisted but became larger as surface temperature decreased and flow increased (Fig. 9). This relationship might seem counterintuitive, since increased mixing might be expected as flow increased, and greater heat loss and turnover might be expected as surface waters cooled and became denser. However, the density of the saline bottom water remained greater than that of the colder, fresher surface water (Fig. 7), resulting in a stable density distribution that prevented the temperature inversion from being disrupted by factors that might cause vertical mixing, such as tidal action or wind.

The amount of freshwater inflow required to create and maintain an effective temperature inverted halocline is likely site-specific. At POI, a surface layer of freshwater roughly $1 \mathrm{~m}$ thick was associated with the pronounced temperature inversion during the severe cold of winter 2009-2010, forming a pycnocline or sharp boundary between layers with different salinities (Fig. A3). Pycnoclines may not be necessary to maintain thermal inversions; partial stratification with a gradual increase in salinity from surface to bottom may inhibit vertical mixing (Dyer 1997). POI appears to lose salinity stratification fairly rapidly as freshwater discharge declines, whereas at BCNP the stratification appears to persist for several weeks or longer even with much reduced freshwater inflow. BCNP was substantially warmer than POI during both winters, with bottom temperatures remaining above $22^{\circ} \mathrm{C}$. BCNP may remain warmer and retain stratification longer than POI at least in part because BCNP has less mixing due to deeper, narrower canals, less flushing due to a more restricted tidal connection and more uneven bathymetry, and higher groundwater influx associated with greater canal depth (Stith et al. 2011).

Other heat-related mechanisms undoubtedly operate at these PTR. Solar radiation is a dominant source of shallow water heat (Ji 2008) and can rapidly warm the entire PTR water column after the passage of cold fronts. Solar gain may be enhanced by certain PTR characteristics, such as presence of windbreaks (e.g. trees, houses), or clear water, which enhances solar penetration. The warmer groundwater and substrate act as a large heat source that conveys heat upward via conduction, but conduction is generally minor compared to advective mechanisms such as groundwater discharge. Heat may also be generated by benthic microorganisms, but relevant studies are lacking or generally attribute a greater role for abiotic sources of heat (Pamatmat 1982, 2003). Additional research is needed to clarify the modes and rates of heat flux, but our results indicate that without 
salinity stratification, heat can be rapidly lost from the entire water column due to convective mixing (Stith et al. 2011). The combination of salinity stratification and groundwater discharge seems to provide the warmest bottom-water temperatures.

The favorable warm water characteristics of POI and BCNP suggest that the creation or management of PTR for manatees could be considered as a management alternative to other sources of warm water, provided sufficient salinity stratification and/or groundwater discharge is present. Canal systems similar to POI or BCNP exist in other parts of the state, and winter aggregations of manatees have been seen at canal systems in Brevard, Miami-Dade, St. Lucie, Palm Beach, and Lee counties (Laist \& Reynolds 2005a,b, Loomis 2010). Useful temperature measurements have been made at some of these sites (Loomis 2010, Barlas et al. 2011), but the role of salinity stratification, groundwater discharge, or tidal pumping remains unclear. Aside from the difficulty and expense of collecting detailed data to characterize PTR, other problems arise once the site conditions and mechanisms are understood. For example, freshwater discharge might be unreliable or unavailable during winter, preventing the establishment of halocline-driven PTR. Even if freshwater were available, numerous competing demands for human use might dictate against water release in winter, especially during drought years, when winter water shortages are especially acute. Most coastal canals with freshwater discharge have salinity-blocking structures that control freshwater flows and levels to meet conflicting goals, including prevention of saltwater intrusion, flood protection, stormwater drainage, conservation of surface water for consumptive uses, aquifer recharge, and maintenance or restoration of healthy aquatic ecosystems (SFWMD 2010). Nevertheless, providing freshwater flow during the winter dry season may be beneficial or important to estuarine health (Fernald \& Purdum 1998, Sklar \& Browder 1998, McVoy et al. 2011), thus PTR management may be compatible with some ecosystem restoration or management goals.

Other habitat needs and risk criteria have been identified for manatee use of canals (Ferrell et al. 2004) that are relevant for PTR. These include (1) manatee accessibility (absence of shallow, narrow restrictions or excessively long distances), (2) availability of nearby food resources, (3) exposure to watercraft traffic, (4) presence of dangerous water control structures, and (5) ability to establish and enforce protection zones at PTR to regulate human disturbance. Additional considerations for creating new warm-water sites have been identified in the Florida Manatee Management Plan (FFWCC 2007), including minimizing reliance on technological solutions, allowing for behavioral adjustments by manatees to adopt new sites and overcome strong site fidelity to old sites, and developing contingency plans to respond to temporary or permanent loss of warm-water habitat.

Given the potential loss or reduction in carrying capacity of some warm-water sites and the associated threat to population viability, identifying, protecting, and enhancing warm-water sites has been a major goal identified for the recovery of manatees (USFWS 2001, FFWCC 2007). This threat may not be reduced in the near future due to climate change, as greater variability and more extreme weather may occur (Kodra et al. 2011), and large-scale changes in circulation patterns associated with loss of sea ice (Liu et al. 2012) or the Arctic Oscillation (Cohen et al. 2010) are expected to continue to produce sporadic cold-air outbreaks from the Artic, irrespective of any global trends in mean temperature. Management of the Florida manatee, as well as other temperaturesensitive species, most likely will continue to require consideration of warm-water availability issues in the foreseeable future. Inventorying and monitoring the state's coastal canals, rivers, or small bays that have potential as halocline-driven and/or groundwaterdriven PTR might help evaluate the potential of PTR from a statewide manatee perspective. Our results suggest that halocline-driven PTR can provide warm-water sites in extreme southwestern Florida and can support large numbers of manatees, but additional research is needed in other areas to determine how these findings might apply to understanding and managing warm-water habitats in other parts of the state.

Acknowledgements. Funding was provided by the following USGS programs: FISCHS Project (Future Impacts of Sea Level Rise on Coastal Habitats and Species), Ecosystems Mapping, Greater Everglades Priority Ecosystems Science (PES), and Critical Ecosystem Studies Initiative (CESI). Funding was also provided by the US Army Corps of Engineers. We thank the following agencies for hydrology or environmental data: South Florida Water Management District, Everglades National Park, Big Cypress National Preserve, Ten Thousand Islands National Wildlife Refuge, and US Geological Survey. We thank L. Lefebvre for many helpful discussions and support related to this work. Discussions with C. Deutsch, A. Spellman, S. Markley, B. Sobzak, and S. Barton were also helpful. Aerial survey and carcass count data were provided by the Florida Fish and Wildlife Conservation Commission. Use of trade or product names does not imply endorsement by the US Government. 


\section{LITERATURE CITED}

Ackerman BB (1995) Aerial surveys of manatees: a summary and progress report. In: O'Shea TJ, Ackerman BB, Percival HF (eds) Population biology of the Florida manatee (Trichechus manatus latirostris). Information and Technology Report 1, National Biological Service, US Dept Interior, Washington DC, p 13-33

Anderson MP (2005) Heat as a ground water tracer. Ground Water 43:951-968

Barlas ME, Deutsch CJ, de Wit M, Ward-Geiger LI (eds) (2011) Florida manatee cold-related unusual mortality event, January-April 2010. Final report to US Fish \& Wildlife Service. Florida Fish and Wildlife Conservation Commission, St. Petersburg, FL

Barton SL (2006) The influence of habitat features on selection and use of a winter refuge by manatees (Trichechus manatus latirostris) in Charlotte Harbor, Florida. MS thesis, University of South Florida, Tampa, FL

Bossart GD, Meisner RA, Rommel SA, Ghim SJ, Jenson AB (2003) Pathological features of the Florida manatee cold stress syndrome. Aquat Mamm 29:9-17

Cohen J, Foster J, Barlow M, Saito K, Jones J (2010) Winter 2009-2010: a case study of an extreme Arctic Oscillation event. Geophys Res Lett 37:L17707, doi:10.1029/2010GL 044256

Constantz JE, Niswonger RG, Stewart AE (2008) Analysis of temperature gradients to determine stream exchanges with ground water. In: Rosenberry DO, LaBaugh JW (eds) Field techniques for estimating water fluxes between surface water and ground water. US Geological Survey, US Dept Interior, Reston, VA, p $117-128$

Decker J, Swain E, Stith B, Langtimm C (2012) Assessing factors affecting the thermal properties of a passive thermal refuge using three-dimensional hydrodynamic flow and transport modeling. J Waterw Port Coast Ocean Eng (in press)

Deutsch CJ, Reid JP, Bonde RK, Easton DE, Kochman HI, O'Shea TJ (2003) Seasonal movements, migratory behavior, and site fidelity of West Indian manatees along the Atlantic coast of the United States. Wildl Monogr 151: $1-77$

Dyer KR (1997) Estuaries: a physical introduction, 2nd edn. J. Wiley and Sons, New York, NY

Edwards HH, Pollock KH, Reynolds JE III, Powell JA (2007) Estimation of detection probability in manatee aerial surveys at a winter aggregation site. J Wildl Manag 71: 2052-2060

Fernald EA, Purdum ED (eds) (1998) Water resources atlas of Florida. Florida State University Press, Tallahassee, FL

Ferrell D, Congdon R, Scotto L, Mortellaro S, Cook P, Mezich R (2004) Manatee suitability survey in the Everglades region of the Central and Southern Florida project CERP Interagency Manatee Task Force. Vero Beach, FL

FFWCC (Florida Fish and Wildlife Conservation Commission) (2007) Florida manatee management plan. Florida Fish and Wildlife Conservation Commission, Tallahassee, FL

Fofonoff P, Millard RC Jr (1983) Algorithms for computation of fundamental properties of seawater. UNESCO Tech Pap Mar Sci, Vol 44. UNESCO, Paris

Fonnesbeck CJ, Edwards HH, Reynolds JE III (2009) A hier- archical covariate model for detection, availability and abundance of Florida manatees at a warm water aggregation site. In: Thomson DL, Cooch EG, Conroy MJ (eds) Modeling demographic processes in marked populations. Environmental and Ecological Statistics Series, Vol 3. Springer, New York, NY, p 563-578

FWRI (Florida Wildlife Research Institute) (2010) Cold-related mortality event winter 2009-2010. Accessed July 28, 2011. http://myfwc.com/research/manatee/rescue-mortalityresponse/mortality-statistics/cold-related-2009-2010/

Ganju NK (2011) A novel approach for direct estimation of fresh groundwater discharge to an estuary. Geophys Res Lett 38:L11402, doi:10.1029/2011GL047718

Harvey RG, Loftus WF, Rehage JS, Mazzotti FJ (2011) Effects of canals and levees on Everglades ecosystems: circular. WEC304. IFAS Extension, University of Florida, Gainesville, FL.

> Irvine AB (1983) Manatee metabolism and its influence on distribution in Florida. Biol Conserv 25:314-334

Ji ZG (2008) Hydrodynamics and water quality: modeling rivers, lakes, and estuaries. John Wiley \& Sons, Hoboken, NJ

Kodra E, Steinhaeuser K, Ganguly AR (2011) Persisting cold extremes under 21st-century warming scenarios. Geophys Res Lett 38:L08705, doi:10.1029/2011GL047103

Laist DW, Reynolds JE III (2005a) Influence of power plants and other warm-water refuges on Florida manatees. Mar Mamm Sci 21:739-765

Laist DW, Reynolds JE III (2005b) Florida manatees, warmwater refuges, and an uncertain future. Coast Manage 33:279-295

Liu J, Curry JA, Wang H, Song M, Horton RM (2012) Impact of declining Arctic sea ice on winter snowfall. Proc Natl Acad Sci USA 109: 4074-4079

Loomis CP (2010) Evaluation of thermal characteristics of secondary warm-water sites for the Florida manatee. MS thesis, Duke University, Durham, NC

McVoy CW, Said WP, Obeysekera J, VanArman JA, Dreshel TW (2011) Landscapes and hydrology of the predrainage Everglades. University Press of Florida, Gainesville, FL

NCDC (National Climatic Data Center) (2010) 2009/2010 cold season. Special reports. Accessed 29 July 2011. www1.ncdc.noaa.gov/pub/data/cmb/special-reports/ 2009-2010-cold-season/2009-2010_Cold_Season.pdf

Pamatmat MM (1982) Heat production by sediment: ecological significance. Science 215:395-397

> Pamatmat MM (2003) Heat-flow measurements in aquatic ecosystems. J Plankton Res 25:461-464

Parkinson RW (1998) Decelerating Holocene sea-level rise and its influence on southwest Florida coastal evolution: a transgressive/regressive stratigraphy. J Sediment Petrol 59:960-972

Reich CD (2010) Investigation of submarine groundwater discharge along the tidal reach of the Caloosahatchee River, southwest Florida. US Geological Survey OpenFile Report 2009-1272. US Geological Survey, US Dept Interior, Reston, VA, p A1-A52

Renken RA, Dixon J, Koehmstedt J, Ishman S and others (2005) Impact of anthropogenic development on coastal ground-water hydrology in southeastern Florida, 19002000. Circular 1275. US Geological Survey, US Dept Interior, Reston, VA

Runge MC, Sanders-Reid CA, Langtimm CA, Fonnesbeck CJ (2007) A quantitative threats analysis for the Florida 
manatee (Trichechus manatus latirostris). U.S. Geological Survey Open-File Report 2007-1086, US Geological Survey, US Dept Interior, Reston, VA. Availalbe at www. pwrc.usgs.gov/resshow/manatee/threats

Scott TM, Means GH, Meegan RP, Means RC and others (2004) Springs of Florida. Florida Geological Survey, Tallahassee, FL

Sklar FH, Browder JA (1998) Coastal environmental impacts brought about by alterations to freshwater flow in the Gulf of Mexico. Environ Manag 22:547-562

SFWMD (South Florida Water Management District) (2010) Canals in south Florida: a technical support document. South Florida Water Management District, West Palm Beach, FL

Stith BM, Slone DH, Reid JP (2006) Review and synthesis of manatee data in Everglades National Park. USGS Administrative Report. USGS Florida Integrated Science Center, Gainesville, FL. Available at fl.biology.
usgs.gov/pdf/Stith_et_al_ENP_Manatee_Administrative _Report.pdf

Stith BM, Reid JP, Langtimm CA, Swain ED, Doyle TJ, Slone DH, Decker JD, Soderqvist LE (2011) Temperature inverted haloclines provide winter warm-water refugia for manatees in southwest Florida. Estuar Coast 34: 106-119

US Army Corps of Engineers and South Florida Water Management District (2004) Comprehensive Everglades restoration plan, Picayune Strand restoration (formerly Southern Golden Gate Estates ecosystem restoration). Final integrated project implementation report and environmental impact statement. Accessed June 2009. www. evergladesplan.org/pm/projects/docs_30_sgge_pir_final .aspx

USFWS (US Fish and Wildlife Service) (2001) Florida manatee recovery plan, (Trichechus manatus latirostris), 3rd edn. US Fish and Wildlife Service, Atlanta, GA

\section{Appendix}

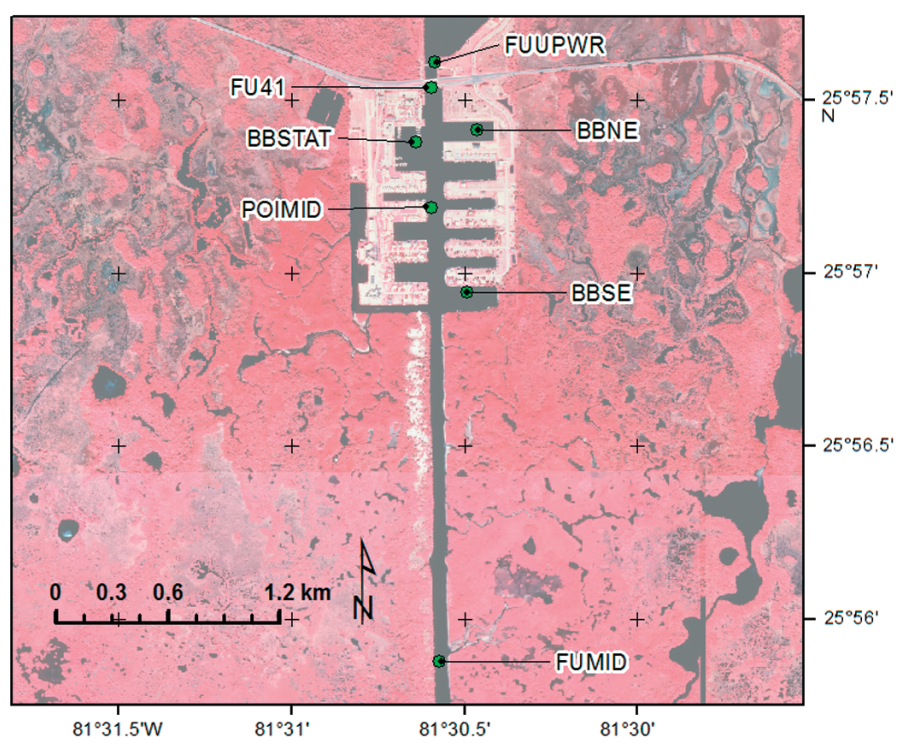

Fig. A1. Color infrared image (water is black, vegetation is red) showing location of continuous monitoring station (BBSTAT) in Port of the Islands and additional sites where grab sample vertical salinity profiles were taken. Sites BBSTAT, BBNE, and BBSE were in deeper holes with heavier manatee use. Crosses show latitude-longitude graticule 


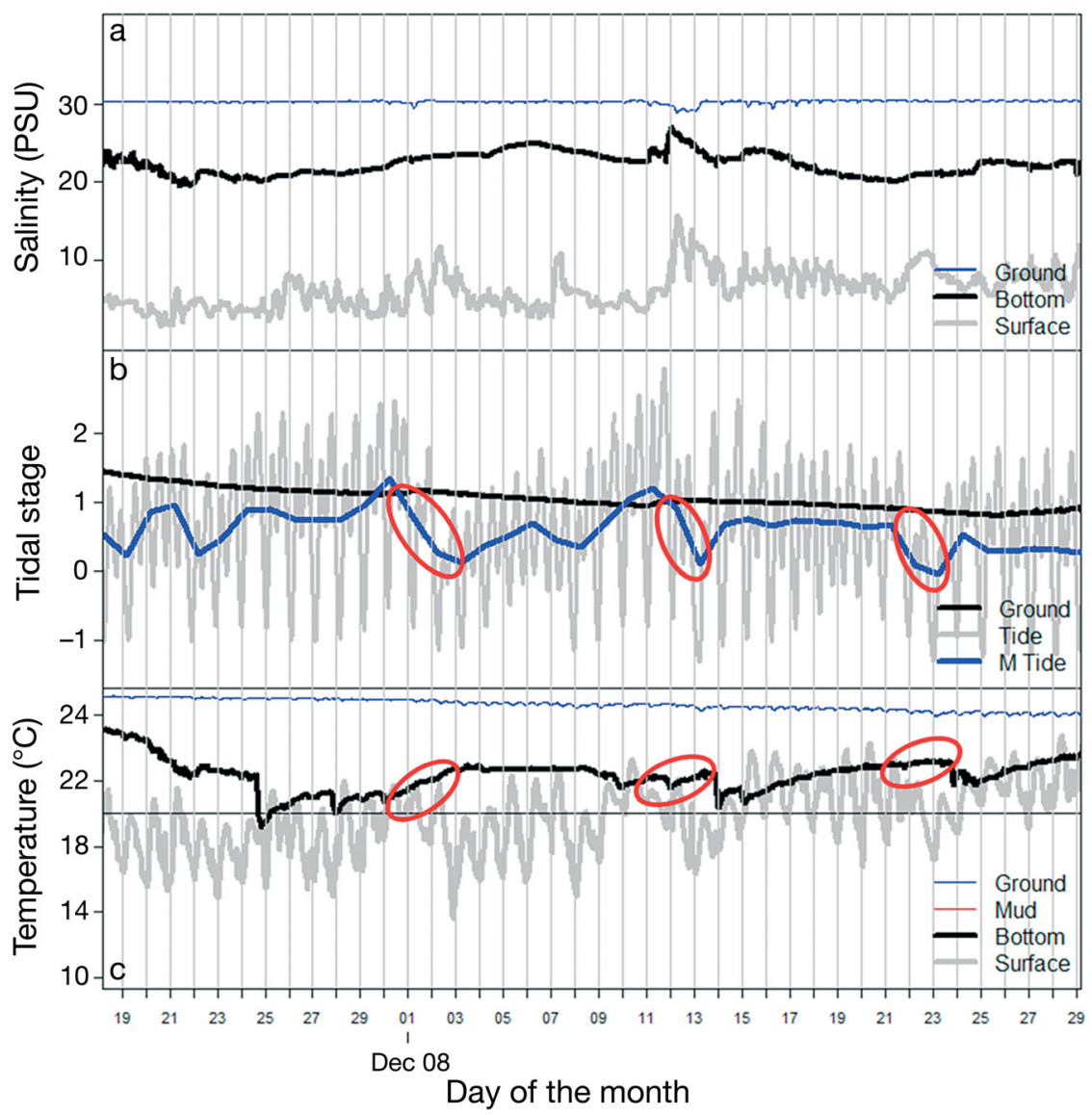

Fig. A2. Port of the Islands (POI) (a) surface and bottom salinities, (b) SGT5W3 groundwater level and POI tide stage (15 min interval, tide; daily mean, $\mathrm{M}$ tide), (c) SGT5W3 groundwater, POI surface and bottom temperatures at $15 \mathrm{~min}$ intervals for November 18 to December 28, 2008. (b) Red ellipses show low tide cycles associated with strong cold events. (c) Red ellipses show corresponding periods with bottom-water warming, surface-water cooling

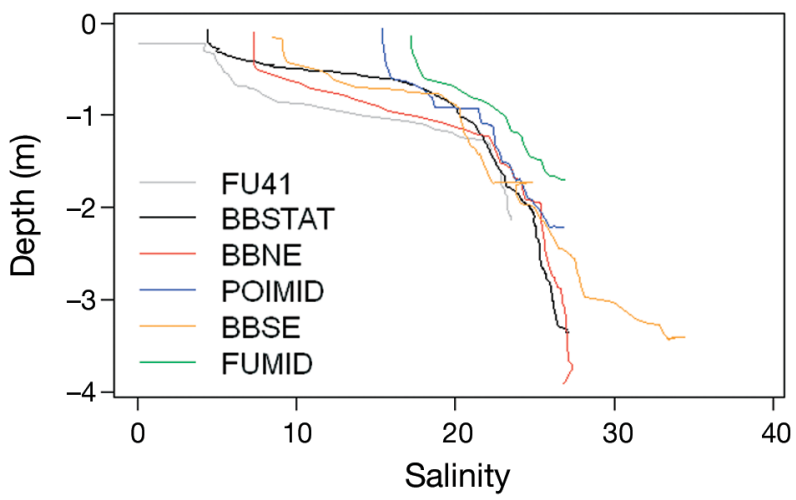

Fig. A3. Port of the Islands vertical salinity profiles for the afternoon of January 8, 2010 at sampling stations shown in

Fig. A1 